\title{
The Contribution of Principals' Leadership Role and Teachers' Integrity to Elementary School Teachers' Performance
}

\section{Alice Yeni Verawati Wote ${ }^{1 *}$, Wiwin Priscilla Sero ${ }^{2}$}

\author{
1,2,3 Pendidikan Guru Sekolah Dasar, Fakultas Keguruan dan Ilmu Pendidikan, Universitas Halmahera, Indonesia
}

\section{A R T I C L E I N F O}

Article history:

Received March 05, 2021

Revised March 08, 2021

Accepted May 11, 2021

Available online May 25, 2021

Kata Kunci:

Representasi Matematis,

Kepribadian

Keywords:

Mathematical Representation,

Personality

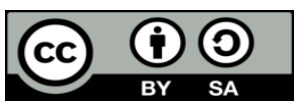

This is an open access article under the CC BY-SA license.

Copyright (C) 2021 by Author. Published by Universitas Pendidikan Ganesha.

\begin{abstract}
A B S T R A K
Guru sebagai salah satu komponen dalam penyelenggaraan pendidikan memiliki kontribusi penting dalam proses penyelenggaraan pendidikan yang berkualitas. Dalam melaksanakan tugasnya, kinerja guru dipengaruhi oleh berbagai faktor. Penelitian ini bertujuan untuk menganalisis kontribusi peran kepemimpinan kepala sekolah dan integritas terhadap kinerja guru sekolah dasar. Penelitian ini merupakan penelitian deskriptif kuantitatif dengan menggunakan metode survei. Populasi dalam penelitian ini adalah guru sekolah dasar. Pengambilan sampel menggunakan teknik random sampling, sehingga diperoleh sampel sebanyak 67 orang guru. Pengumpulan data dalam penelitian ini menggunakan instrumen berupa kuesioner peran kepemimpinan kepala sekolah, kuesioner integritas guru, dan kuesioner kinerja guru. Data yang telah dikumpulkan kemudian dianalisis dengan menggunakan teknik analisis regresi berganda. Hasil penelitian menunjukkan bahwa peran kepemimpinan kepala sekolah berpengaruh positif dan signifikan terhadap kinerja guru sekolah dasar; integritas guru berpengaruh positif dan signifikan terhadap kinerja guru sekolah dasar; peran kepemimpinan kepala sekolah dan integritas guru secara simultan berpengaruh positif dan signifikan terhadap kinerja guru sekolah dasar. Penelitian ini menunjukkan bahwa baik buruknya kinerja guru dipengaruhi oleh integritas yang dimiliki oleh guru dan peran kepemimpinan kepala sekolah.
\end{abstract}

\section{A B S T R A C T}

Teachers have an important contribution in the process of providing quality education. In carrying out their duties, teacher performance is influenced by various factors. This study aims to analyze the contribution of the principal's leadership role and integrity to the performance of elementary school teachers. This research is a quantitative descriptive study using a survey method. The population in this study was elementary school teachers. Sampling using random sampling technique, to obtain a sample of 67 teachers. The data collected in this study used instruments in the form of a principal leadership role questionnaire, a teacher integrity questionnaire, and a teacher performance questionnaire. The data that has been collected is then analyzed using multiple regression analysis techniques. The results showed that the principal's leadership role had a positive and significant effect on the performance of elementary school teachers; teacher integrity has a positive and significant effect on the performance of elementary school teachers; principal's leadership role and teacher integrity simultaneously have a positive and significant effect on the performance of elementary school teachers. This study shows that the good and bad performance of teachers is influenced by the integrity of the teacher and the leadership role of the principal.

\section{INTRODUCTION}

Schools as formal educational institutions play an important role in improving the quality of education to educate the nation's life (Billy \& Taat, 2020; Maskuri, 2018). Improving the quality of education requires principals who can carry out their duties and functions well and improve the performance of teachers (Leniwati \& Arafat, 2017; Suchyadi et al., 2019). herefore school leaders must be able to influence their subordinates (Navaridas-Nalda et al., 2020; Suriansyah \& Aslamiah, 2015). Leadership is the process of influencing, commanding persuasively, setting an example, and guiding others to achieve the goals that have been set (Sagala, 2011; Yayuk \& Sugiyono, 2019). The principal as a leader has a very important role to help teachers and staff (Gaol \& Siburian, 2018). In carrying out its leadership function, it must depend on its ability (Cheng \& Szeto, 2016; Sholeh, 2017). In connection with that, the roles and functions that must be carried out properly by the principal as a leader include educators, managers, administrators, supervisors, leaders, innovators, and motivators (Mulyasa, 2004; Sanders, 2014). The main priority of these roles and functions is to improve learning situations and improve the performance of teachers who handle them (Auliya et al., 2012; Utami, 2017). 
In carrying out his leadership function, principals must manage and foster schools through various activities such as leadership or management and leadership activities which are very dependent on their abilities (Carudin, 2011; Drago-Severson, 2012). In connection with that, the principal as a supervisor functions to supervise, build, correct and seek initiatives for the course of all educational activities carried out in the school environment (Leniwati \& Arafat, 2017; Maulid, 2017). Besides that, the principal as an educational leader functions to create harmonious human relationships to foster and develop interpersonal cooperation, so that they simultaneously move towards achieving goals through the willingness to carry out their respective duties efficiently and effectively (Hallinger, 2005; Hallinger et al., 1996). Therefore, all the implementation of education will lead to efforts to improve the quality of education which is strongly influenced by teachers in carrying out their duties operationally. The roles and functions that must be carried out by the principal as a leader include educators, managers, administrators, supervisors, leaders, innovators, and motivators (Ekosiswoyo, 2016; Mulyasa, 2004; Sholeh, 2017). The main priority of these roles and functions is to improve learning situations and improve the performance of teachers who handle them (Septiana \& Ivada, 2013; Wahjosumijo, 2010).

Principal leadership is the ability of functional teachers who are given the task to lead a school and mobilize all available resources so that they can be utilized optimally to achieve the goals that have been set (Iskandar, 2013; Maris et al., 2016). For educational goals in a school to be realized properly, this requires the figure of an educational leader who understands well what the function of leadership in a school is, the duties and responsibilities of an educational leader (Minsih et al., 2019; Pianda, 2018). Principals as leaders in schools have roles and functions that must be carried out properly including as educators, managers, administrators, supervisors, leaders, innovators and motivators (Mulyasa, 2004). As a leader, the principal must also be able to provide influences that can cause teachers to be moved to carry out their duties effectively so that teacher performance will be better. That is why the principal's leadership can improve the integrity of a teacher (Messi \& Harapan, 2017). Integrity is consistency and firmness that can be shaken in upholding noble values and beliefs (McKenney et al., 2013; Rosyati et al., 2020). A person's integrity can be seen from: first, personality; second, Honesty; third, temperament; fourth, Character; and fifth; hard work. Individual character or integrity affects performance with three indicators, namely cognitive ability, work experience and personality traits/accuracy (Melancon et al., 1994; Sarjana \& Khayati, 2016). So whether or not a teacher's performance depends on his or her integrity.

Meanwhile, teacher performance in schools has an important role in achieving school goals (Priansa \& Euis, 2013; Setiyati, 2014). Based on observations, it was found that the performance of teachers in carrying out their duties as educators was still low because they still considered that teachers were only carrying out their duties routinely, such as teachers not making adequate plans in carrying out teaching tasks, making lesson plans only to fulfill administrative requirements and not preparing learning Media. In addition, the integrity of teachers in carrying out their duties is also still low, this is evidenced by the existence of teachers who carry out their duties properly if there is the supervision of the principal as a leader in the school. Meanwhile, the principal as a school leader gives too much freedom to teachers in carrying out their duties, does not give warnings and punishments for teachers whose performance is not good. So that it has an impact on the low morale and sense of responsibility of teachers in carrying out their duties. This study aims to analyze the contribution of the principal's leadership role and integrity to the performance of elementary school teachers.

\section{METHOD}

This research is a quantitative descriptive study using a survey method (Creswell, 2014; Sugiono, 2014). The variables of this research are the principal's leadership role (X1), teacher integrity (X2), and teacher performance (Y). The research framework and the relationship between variables in this study are presented in Figure 1. The population in this study were elementary school teachers in Sahu District, West Halmahera Regency. Determination of the sample is done by using the random sampling technique. Through this technique, the research sample obtained was 67 teachers spread across eight elementary schools in Kecamatan Sahu, Kabupaten Halmahera Barat. Data collection in this study used an instrument in the form of a questionnaire. The questionnaires included a principal leadership role questionnaire, a teacher integrity questionnaire, and a teacher performance questionnaire. All of the questionnaire instruments have been tested for validity and reliability. Data analysis in this study used multiple regression analysis techniques. Data analysis was preceded by descriptive analysis, prerequisite analysis test in the form of normality test and linearity test then continued with regression analysis. All analysis processes were carried out using the help of the IBM SPSS Statistics 21.0 program. 


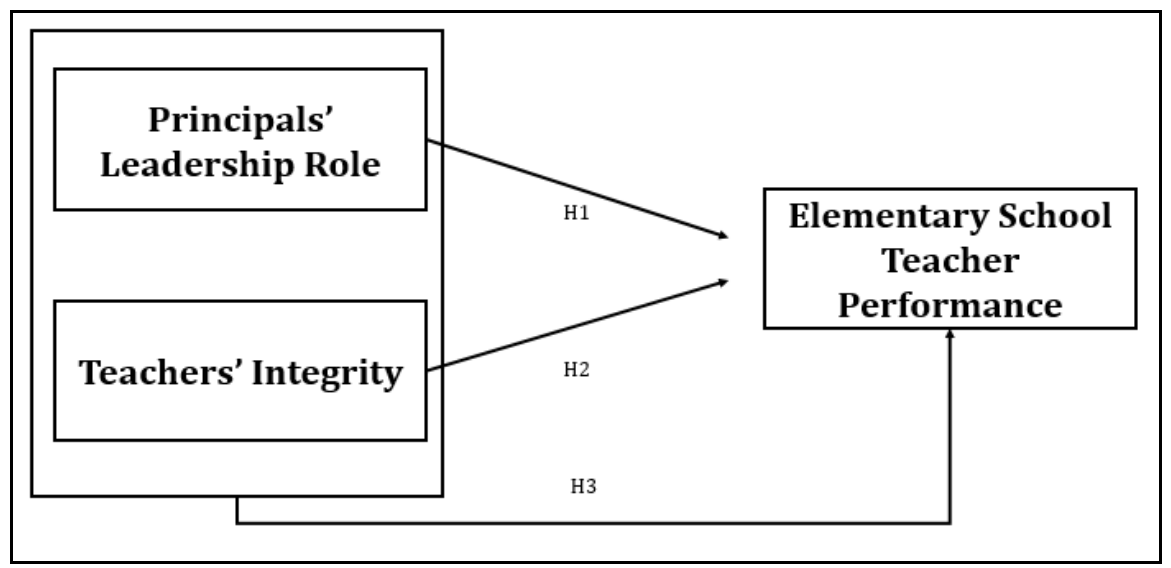

Figure 1. Research Framework

\section{RESULT AND DISCUSSION}

\section{Result}

\section{Descriptive Analysis}

The research data on the variables of the principal's leadership role (X1), teacher integrity (X2) and teacher performance (X2), which have been analyzed through descriptive statistics are presented in Table 1.

Table 1. Descriptive Analysis Results

\begin{tabular}{cccc}
\hline Statistics & Principals' Leadership Role & Teachers' Integrity & Teacher Performance \\
\hline N & 67 & 67 & 67 \\
Mean & 305.49 & 173.63 & 125.63 \\
Std. Error & 2.832 & 1.991 & 1.023 \\
Variance & 537.254 & 265.692 & 70.086 \\
Range & 84 & 60 & 27 \\
Minimum & 251 & 140 & 113 \\
Maximum & 335 & 200 & 140 \\
\hline
\end{tabular}

\section{Prerequisite Analysis Test}

The prerequisite analysis test is carried out which includes the normality test and linearity test. Normality test was performed using the One-Sample Kolmogorov-Smirnov Test. The summary of the results of the normality test is presented in Table 2 ..

Table 2. Normality Test Results

\begin{tabular}{cccc}
\hline Variable & Asymp. Sig & Alpha & Conclusion \\
\hline Principals' Leadership Role & 0.80 & 0.05 & Normal \\
Teachers' Integrity & 0.60 & 0.05 & Normal \\
Teacher Performance & 0.10 & 0.05 & Normal \\
\hline
\end{tabular}

Furthermore, the results of the significance and linearity tests for each of the effects of the principal's leadership role and teacher integrity on teacher performance are presented in Table 3.

Table 3. Linearity Test Results

\begin{tabular}{cccc}
\hline Variable & Sig. of Linearity & Sig. of Deviation from Linearity & Conclusion \\
\hline Principals' Leadership Role & 0.000 & 0.280 & Linear \\
Teachers' Integrity & 0.000 & 0.300 & Linear \\
\hline
\end{tabular}

\section{Research Hypothesis Test}

After various analyzes were carried out, hypothesis testing was then carried out to measure the magnitude of the positive influence between the research variables. The description of the results of calculations that have been carried out using regression analysis is described as follows. 


\section{The Influence of the Principal's Leadership Role on Teacher Performance}

Based on the results of data analysis conducted, it can be seen that there is a positive and significant influence between the leadership role of the principal on teacher performance, this is shown by looking at the value of $r_{\text {count }}(0,462)>r_{\text {table }}(0,236)$. The coefficient of determination $r_{\text {square }}$ is 0,214 , which means $21,4 \%$ change in the teacher performance variable $(\mathrm{Y})$ which is influenced by the principal's leadership and $78,6 \%$ is influenced by other factors. From the $t$ test, it can also be seen that the $t_{\text {count }}$ is 4,205 and when compared with $t_{\text {table }}(1,997)$ at the $5 \%$ level, $t_{\text {count }}>t_{\text {table. }}$ From the $F$ test, it can be seen that $F_{\text {count }} 17.680>F_{\text {table }} 3.99$ (significance 5\%, df 1.65). The regression line equation for the influence of the principal's leadership role on teacher performance can be expressed as $\widehat{Y}=74,604+0,167 \mathrm{X}_{1}$. The equation shows that the $\mathrm{X} 1$ coefficient value is 0.167 , which means that if the leadership role of the principal (X1) increases by 1 point, the teacher's performance $(\mathrm{Y})$ will increase by 0.167 points. From this explanation, the working hypothesis $\mathrm{H} 1$ is accepted and $\mathrm{H} 0$ is rejected, so there is a positive and significant influence on the principal's leadership role on teacher performance.

\section{The Effect of Teacher Integrity on Teacher Performance}

Based on the results of the data analysis conducted, it can be seen that there is a positive and significant influence between the principal's leadership role on teacher performance. This is shown by looking at the price of $r_{\text {count }}(0.478)>r_{\text {table }}(0.236)$. The coefficient of determination rsquare is 0.228 , which means $22.8 \%$ change in the teacher performance variable $(\mathrm{Y})$ which is influenced by integrity and $77.2 \%$ is influenced by other factors. From the $t$-test it can also be seen that the $t_{\text {count }}$ is 4.382 and when compared with $\mathrm{t}_{\text {table }}(1.997)$ at the $5 \%$ level, $\mathrm{t}_{\text {count }}>\mathrm{t}_{\text {table. }}$. From the $\mathrm{F}$ test, it can be seen that $\mathrm{F}_{\text {count }} 19.199>$ $\mathrm{F}_{\text {table }} 3.99$ (significance 5\%, df 1.65). The regression line equation for the influence of integrity on teacher performance can be expressed by $\widehat{Y}=83,044+0,245 \mathrm{X}_{2}$. The equation shows that the $\mathrm{X} 2$ coefficient value is 0.245 , which means that if the integrity (X2) increases by 1 point, the teacher's performance $(\mathrm{Y})$ will increase by 0.245 points. From this explanation, the working hypothesis $\mathrm{H} 2$ is accepted and $\mathrm{H} 0$ is rejected, so there is a positive and significant effect of integrity on teacher performance.

\section{The Influence of the Principal's Leadership Role and Teacher Integrity on Teacher Performance}

Based on the results of data analysis carried out, it can be seen that $r_{\text {count }}(0.571)>r_{\text {table }}(0.236)$. The coefficient of determination rsquare is 0.326 which means $32.6 \%$ change in the teacher performance variable $(\mathrm{Y})$ which is influenced by the principal's leadership role and integrity. This shows that there are still $67.4 \%$ of other factors or variables that affect teacher performance other than the principal's leadership role and integrity. Then carried out simultaneous testing (Test F). Simultaneous testing aims to determine together the influence of the role of principal leadership (X1) and integrity (X2) on teacher performance $(\mathrm{Y})$, and the coefficient of simultaneous determination to determine the magnitude of the contribution together independent variable to the dependent variable.

Based on the results of data analysis carried out, it can be seen that the results of the $\mathrm{F}$ test obtained $F_{\text {count }}$ of 15,469 . When compared with Ftable with df 2.64 and a significance level of $5 \%$ so that

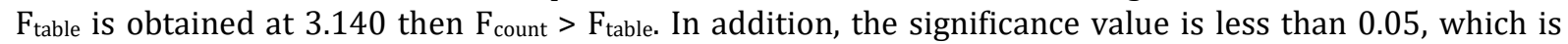
0.00 , it can be interpreted that the relationship between the principal's leadership role and integrity together with teacher performance is significant. Then in making the regression line equation the results are presented as in Table 4.

Table 4. Regression Test Results

\begin{tabular}{|c|c|c|c|c|c|}
\hline \multirow[t]{2}{*}{ Model } & \multicolumn{2}{|c|}{$\begin{array}{l}\text { Unstandardized } \\
\text { Coefficients }\end{array}$} & \multirow{2}{*}{$\begin{array}{l}\text { Standardized } \\
\text { Coefficiens } \\
\text { Beta }\end{array}$} & \multirow[t]{2}{*}{$\mathbf{T}$} & \multirow[t]{2}{*}{ Sig. } \\
\hline & Beta & Std. Error & & & \\
\hline (Constant) & 56.741 & 12.608 & & & \\
\hline Principals' Leadership Role & 0.121 & 0.040 & 0.335 & 3.048 & 0.003 \\
\hline Teacher Performance & 0.184 & 0.056 & 0.358 & 3.261 & 0.002 \\
\hline
\end{tabular}

The regression line equation for the influence of the principal's leadership role and the integrity of the teacher together on teacher performance can be expressed by $\hat{Y}=56,741+0,121\left(X_{1}\right)+0,184\left(X_{2}\right)$. The equation shows that the $\mathrm{X} 1$ coefficient value is 0.121 , which means that if the leadership role of the principal (X1) increases by 1 point, the teacher's performance $(\mathrm{Y})$ will increase by 0.121 points with the assumption that $\mathrm{X} 2$ remains. The $\mathrm{X} 2$ coefficient is 0.184 , which means that if the integrity (X2) increases by 1 point, the teacher's performance $(\mathrm{Y})$ will increase by 0.184 with the assumption that $\mathrm{X} 1$ remains. 
From this explanation, it can be concluded that there is a simultaneous positive and significant influence between the principal's leadership role and performance on teacher performance.

\section{Discussion}

\section{The Influence of the Principal's Leadership Role on Teacher Performance}

The results of the research compiled by the researcher indicated that the leadership role of the principal affects the performance of teachers in public elementary schools throughout the Kecamatan Sahu, Kabupaten Halmahera Barat, namely, the better the leadership role of the principal, the better the teacher's performance and the worse the leadership role of the principal, the better. the teacher's performance is bad. The results of this study are supported by a theory which states that whether or not teacher performance in schools is very dependent on the ability of the principal in influencing teacher behavior in carrying out their duties (Finnigan \& Stewart, 2009; Gumus, 2013; Marks \& Printy, 2003). A teacher can carry out his duties well if he tends to submit to the principal so that everything that is carried out by the teacher refers to the policies of the principal. In addition, teacher performance is strongly influenced by the principal's role as a leader in the school (Hoppey \& McLeskey, 2013; Sunengsih, 2015; Wibowo, 2009). Thus, teacher performance will be good if the leadership of the principal is also good so that the educational goals set can be achieved properly.

\section{The Effect of Teacher Integrity on Teacher Performance}

This study shows that the good or bad performance of a teacher is determined by the integrity of a teacher. This is following the theory of Andrian Gostik \& Dana Telford, that teachers with integrity in themselves will affect their performance (Santoro, 2017; Sarjana \& Khayati, 2016; Sunengsih, 2015). Someone who has integrity in his life will do things according to what he believes. It means that the teacher's performance will be good if the teacher has integrity in himself so that in carrying out his duties the teacher remains on the principle of life that teaching and educating is a duty and responsibility to be able to achieve the goal of education, namely the intellectual life of the nation.

\section{The Influence of the Principal's Leadership Role and Teacher Integrity on Teacher Performance}

The third result of this study shows that the principal's leadership role and integrity jointly affect teacher performance, namely, the better the principal's leadership role, and integrity, the better the teacher's performance. the worse the teacher's performance. From the results of this study, it is suggested to Principals as leaders in schools must be able to carry out their main duties and functions better and maximally so that they can become role models and improve teacher performance in schools; Teachers must have good integrity in themselves so that in carrying out their duties and responsibilities at school, they can be carried out properly, without having to be supervised. Thus the performance of teachers in schools will be maximized and become better; Teachers as educators must be able to develop themselves to improve performance in schools to the maximum and become better; The education office as an organization that can control and organize an educational institution, especially in Kecamatan Sahu, Kabupaten Halmahera Barat, must be able to further improve the competence of principals and teachers so that the learning process that takes place in schools can achieve optimal educational goals.

\section{CONCLUSION}

The principal's leadership role has a positive and significant effect on teacher performance; Integrity has a positive and significant effect on teacher performance; The principal's leadership role and integrity simultaneously have a positive and significant effect on teacher performance. Principals as leaders in schools must be able to carry out their main duties and functions better and maximally so that they can be role models and improve teacher performance in schools. can be implemented properly, without having to be supervised. Thus the performance of teachers in schools will be maximized and become better.

\section{REFERENCES}

Auliya, U. U., Thomas, P., \& Latifah, L. (2012). Pengaruh Supervisi Kepala Sekolah Dan Motivasi Kerja Guru Terhadap Kinerja Guru. Economic Education Analysis Journal, 1(2), 1-9. https://journal.unnes.ac.id/sju/index.php/eeaj/article/download/520/546.

Billy, L. J., \& Taat, M. S. (2020). Budaya Sekolah: Hubungannya dengan Komitmen Guru. Malaysian Journal of Social Sciences and Humanities (MJSSH), 5(10), 207-216. https://doi.org/10.47405/mjssh.v5i10.511. 
Carudin, C. (2011). Pengaruh Kepemimpinan Kepala Sekolah dan Iklim Kerja Sekolah terhadap Kinerja Guru. INVOTEC, 7(2). https://doi.org/10.17509/invotec.v7i2.6289.

Cheng, A. Y. N., \& Szeto, E. (2016). Teacher leadership development and principal facilitation: Novice teachers' perspectives. Teaching and Teacher Education, 58, 140-148. https://doi.org/10.1016/j.tate.2016.05.003.

Creswell, W. J. (2014). Research Design: qualitatative, quantitative, and mixed method approach. SAGE Publications.

Drago-Severson, E. (2012). New opportunities for principal leadership: Shaping school climates for enhanced teacher development. Teachers College Record, 114(3), 1-44. https: //www.tcrecord.org/Content.asp?ContentId=16304.

Ekosiswoyo, R. (2016). Kepemimpinan kepala sekolah yang efektif kunci pencapaian kualitas pendidikan. Jurnal Ilmu Pendidikan, 14(2). http://journal.um.ac.id/index.php/jip/article/view/24.

Finnigan, K. S., \& Stewart, T. J. (2009). Leading change under pressure: An examination of principal leadership in low-performing schools. Journal of School Leadership, 19(5), 586-621. https: //doi.org/10.1177\%2F105268460901900504.

Gaol, N. T. L., \& Siburian, P. (2018). Peran Kepala Sekolah Dalam Meningkatkan Kinerja Guru. Kelola: Jurnal Manajemen Pendidikan, 5(1), 66-73. https://doi.org/10.24246/j.jk.2018.v5.i1.p66-73.

Gumus, S. (2013). The effects of teacher-and school-level factors on teachers participation in professional development activities: The role of principal leadership. Journal of International Education Research (JIER), 9(4), 371-380. https://doi.org/10.19030/jier.v9i4.8089.

Hallinger, P. (2005). Instructional leadership and the school principal: A passing fancy that refuses to fade away. Leadership and Policy in Schools, 4(3), 221-239. https: //doi.org/10.1080/15700760500244793.

Hallinger, P., Bickman, L., \& Davis, K. (1996). School context, principal leadership, and student reading achievement. The Elementary School Journal, 96(5), 527-549. https://doi.org/10.1086/461843.

Hoppey, D., \& McLeskey, J. (2013). A case study of principal leadership in an effective inclusive school. The Journal of Special Education, 46(4), 245-256. https://doi.org/10.1177\%2F0022466910390507.

Iskandar, U. (2013). Kepemimpinan kepala sekolah dalam peningkatan kinerja guru. Jurnal Visi Ilmu Pendidikan, 10(1). https://doi.org/10.26418/jvip.v10i1.2061.

Leniwati, L., \& Arafat, Y. (2017). Implementasi Supervisi Akademik Kepala Sekolah Untuk Meningkatkan Kinerja Guru. JMKSP (Jurnal Manajemen, Kepemimpinan, Dan Supervisi Pendidikan), 2(1), 106114. https://doi.org/10.31851/jmksp.v2i1.1158.

Maris, I. S., Komariah, A., \& Bakar, A. (2016). Kepemimpinan transformasional kepala sekolah, kinerja guru dan mutu sekolah. Jurnal Administrasi Pendidikan, 23(2). https://doi.org/10.17509/jap.v23i2.5645.

Marks, H. M., \& Printy, S. M. (2003). Principal leadership and school performance: An integration of transformational and instructional leadership. Educational Administration Quarterly, 39(3), 370397. https://doi.org/10.1177\%2F0013161X03253412.

Maskuri. (2018). Pendidikan Karakter Disiplin Di Lingkungan Sekolah. Jurnal Tawadhu, 2(1), 340-363. https://ejournal.iaiig.ac.id/index.php/TWD/article/view/3.

Maulid, A. (2017). Pengaruh Supervisi Kepala Sekolah Dan Pengembangan Tenaga Pendidik Terhadap Kinerja Guru Madrasah Aliyah Swasta Di Kabupaten Lima Puluh Kota. JMKSP (Jurnal Manajemen, $\begin{array}{llll}\text { Kepemimpinan, Dan } & \text { Supervisi } & \text { Pendidikan), }\end{array}$ https://doi.org/10.31851/jmksp.v1i2.1010.

McKenney, E. L., Waldron, N., \& Conroy, M. (2013). The effects of training and performance feedback during behavioral consultation on general education middle school teachers' integrity to functional analysis procedures. Journal of Educational and Psychological Consultation, 23(1), 6385. https://doi.org/10.1080/10474412.2013.757152.

Melancon, J. G., Thompson, B., \& Becnel, S. (1994). Measurement integrity of scores from the FennemaSherman Mathematics Attitudes Scales: The attitudes of public school teachers. Educational and Psychological Measurement, $\quad$ 54(1), 187-192. https://doi.org/10.1177\%2F0013164494054001024.

Messi, M., \& Harapan, E. (2017). Menanamkan Nilai Nilai Kejujuran Di Dalam Kegiatan Madrasah Berasrama (Boarding School). JMKSP (Jurnal Manajemen, Kepemimpinan, Dan Supervisi Pendidikan), 2(2), 278-290. https://doi.org/10.31851/jmksp.v2i2.1476.

Minsih, M., Rusnilawati, R., \& Mujahid, I. (2019). Kepemimpinan Kepala Sekolah Dalam Membangun Sekolah Berkualitas Di Sekolah Dasar. Profesi Pendidikan Dasar, 6(1), 29-40. https://journals.ums.ac.id/index.php/ppd/article/view/8467.

Mulyasa. (2004). Manajemen Berbasis Sekolah : Konsep, strategi dan Implementsi. PT. Remaja Rosdakarya. 
Navaridas-Nalda, F., Clavel-San Emeterio, M., Fernández-Ortiz, R., \& Arias-Oliva, M. (2020). The strategic influence of school principal leadership in the digital transformation of schools. Computers in Human Behavior, 112(December 2019). https://doi.org/10.1016/j.chb.2020.106481.

Pianda, D. (2018). Kinerja guru: kompetensi guru, motivasi kerja dan kepemimpinan kepala sekolah. Jejak Publisher.

Priansa, D. J., \& Euis, K. (2013). Kinerja dan Profesionalisme Kepala Sekolah. Alfabeta.

Rosyati, T., Saprudin, S., \& Alaydrus, A. S. (2020). Kinerja OCB pada guru PAUD ditinjau dari Educational leadership dan Integritas. Jurnal Obsesi: Jurnal Pendidikan Anak Usia Dini, 5(1), 201-211. https://doi.org/10.31004/obsesi.v5i1.513.

Sagala, S. (2011). Kemampuan Profesionalisme guru dan tenaga kependidikan. Alfabeta.

Sanders, M. G. (2014). Principal leadership for school, family, and community partnerships: The role of a systems approach to reform implementation. American Journal of Education, 120(2), 233-255. https://doi.org/10.1086/674374.

Santoro, D. A. (2017). Teachers' expressions of craft conscience: upholding the integrity of a profession. Teachers and Teaching, 23(6), 750-761. https://doi.org/10.1080/13540602.2016.1228627.

Sarjana, S., \& Khayati, N. (2016). Pengaruh etika, perilaku, dan kepribadian terhadap integritas guru. Jurnal Pendidikan Dan Kebudayaan, 1(3), 379-393. https://doi.org/10.24832/jpnk.v1i3.450.

Septiana, R., \& Ivada, E. (2013). Pengaruh kepemimpinan kepala sekolah dan motivasi kerja terhadap kinerja guru SMP Negeri Wonosari. Jupe-Jurnal Pendidikan Ekonomi, 2(1). https://jurnal.fkip.uns.ac.id/index.php/ekonomi/article/view/2709.

Setiyati, S. (2014). Pengaruh kepemimpinan kepala sekolah, motivasi Kerja, dan budaya sekolah terhadap kinerja guru. Jurnal Pendidikan Teknologi Dan Kejuruan, 22(2), 200-206. https://doi.org/10.21831/jptk.v22i2.8931.

Sholeh, M. (2017). Keefektifan Peran Kepala Sekolah dalam Meningkatkan Kinerja Guru. JDMP (Jurnal Dinamika Manajemen Pendidikan), 1(1), 41-54. https://doi.org/10.26740/jdmp.v1n1.p41-54.

Suchyadi, Y., Karmila, N., \& Safitri, N. (2019). Kepuasan Kerja Guru Ditinjau Dari Peran Supervisi Kepala Sekolah Dasar Negeri Di Kecamatan Bogor Utara. Jurnal Pendidikan \& Pengajaran Guru Sekolah Dasar, 2(2), 91-94. https://doi.org/10.33751/jppguseda.v2i2.1453.

Sugiono. (2014). Metode Penelitian Kuantitatif, Kualitatif dan R \& D. Alfabetha cv.

Sunengsih, N. D. (2015). Hubungan Profesionalisme, Iklim Sekolah, Dan Integritas Dengan Kinerja Guru SMP Negeri Di Kota Administrasi Jakarta Timur. Jurnal Manajemen, 19(2), 190-204. https://doi.org/10.24912/jm.v19i2.123.

Suriansyah, A., \& Aslamiah, A. (2015). Strategi kepemimpinan kepala sekolah, guru, orang tua, dan masyarakat dalam membentuk karakter siswa. Jurnal Cakrawala Pendidikan, 2(2), 234-247. https://doi.org/10.21831/cp.v2i2.4828.

Utami, S. (2017). Penerapan Supervisi Klinis untuk Meningkatkan Kinerja Guru dalam Proses Belajar Mengajar Gugus IV Sanankulon. Briliant: Jurnal Riset Dan Konseptual, 2(3), 272. https://doi.org/10.28926/briliant.v2i3.70.

Wahjosumijo. (2010). Kepemimpinan Kepala Sekolah. PT Raja Grafindo Persada.

Wibowo. (2009). Manajemen Kinerja. Rajawali Pers.

Yayuk, S., \& Sugiyono, S. (2019). Pengaruh kepemimpinan kepala sekolah dan biaya pendidikan terhadap kualitas proses belajar mengajar dan dampaknya dengan kompetensi lulusan SMK di kabupaten Gunungkidul. Jurnal Akuntabilitas Manajemen Pendidikan, 7(1), 84-96. https://doi.org/10.21831/amp.v7i1.23758. 